Research Article

\title{
Bioadsorption of Basic Blue Dye from Aqueous Solution onto Raw and Modified Waste Ash as Economical Alternative Bioadsorbent
}

\author{
Adugna Nigatu Alene $\mathbb{D}^{D}$, Gietu Yirga Abate, and Adere Tarekegne Habte \\ Department of Chemistry, Woldia University, Woldia, Ethiopia \\ Correspondence should be addressed to Adugna Nigatu Alene; adugnanigatu123@gmail.com
}

Received 3 February 2020; Revised 3 May 2020; Accepted 19 May 2020; Published 15 June 2020

Academic Editor: Clara Cilindre

Copyright (C) 2020 Adugna Nigatu Alene et al. This is an open access article distributed under the Creative Commons Attribution License, which permits unrestricted use, distribution, and reproduction in any medium, provided the original work is properly cited.

\begin{abstract}
Background. Dyes are one of the most hazardous materials in industrial effluents which can cause several health problems in living organisms. The removal of dye from colored effluents has attracted increasing attention in the last decade. In this study, raw, beneficiated, and activated waste ash were evaluated as adsorbents for removal of methylene blue (MB) from aqueous solution by the batch adsorption method. Comprehensive characterization studies were carried out on each bioadsorbent, such as proximate analyses, bulk density, specific surface area, point of zero charge, $\mathrm{pH}$, and Fourier transform infrared (FTIR) spectroscopy (which shows functional groups on adsorbents surface). The effects of $\mathrm{pH}$, adsorbent dosage, initial dye concentration, and contact time were determined in order to know the optimum condition and adsorption potential of the adsorbents. The methylene blue (MB) removal efficiency of raw, beneficiated, and activated bioadsorbents from aqueous solutions was found to be $95.212 \%, 89.172 \%$, and $84.504 \%$, respectively. It is reported that adsorption efficiency of $\mathrm{MB}$ on each adsorbent was quite different due to electrostatic and dispersion interaction between the dye molecules and the surface property of the adsorbents. The obtained results were well fitted with the Freundlich isotherm model, and the adsorption process follows the pseudo-second-order kinetics model for all adsorbents. In fact, the results showed that raw, beneficiated, and activated waste ash bioadsorbents could be employed as effective and economical alternative material in the near future.
\end{abstract}

\section{Background}

Many manufacturing industries such as textile, paper, plastics, cosmetics, leather, and food use dyes for coloring their products [1]. About $50 \%$ of the total world production of dyes goes off during the dyeing process and has been released in textile effluents [2]. Those considerable amounts of dyes are lost and discharged into water streams, which ultimately affects the aquatic life. In addition, the colored effluents are known to be carcinogenic and highly toxic to living things in contact by different mechanisms [3]. Among those dyes, methylene blue is one of the basic (cationic) and heterocyclic aromatic compounds. It has many applications which include coloring paper and dyeing textile products (wool, silk, cotton), in addition to its use in leather industries. In spite of its several applications, this dye has a number of negative impacts (if swallowed or made in contact with skin or eye) on human beings and animals, such as irritation of mouth, throat, and stomach with symptoms of nausea, vomiting, shock, diarrhea, increased heartbeat, cyanosis, jaundice, and tissue necrosis in humans [1, 4]. Undesirable dye pollution is required to be removed from wastewater before being discharged to the environment. Several physical and chemical treatment methods such as adsorption, oxidation, biodegradation, chemical coagulation/flocculation, and chemical precipitation have been used for the treatment of wastewater containing dyes [4-6]. Adsorption is one of the physiochemical methods found to be the most simple and economical to remove the dyes from effluents [7]. Several adsorbents have been reported in the literature such as ground eggshell waste [8], modified silica gel [9], tobacco steam ash [10], rice hull ash [11], tea waste 
[12], coffee grounds [13], fishery waste [14], coconut shell activated carbon [15], agricultural waste products [16], Jatropha curcas pods [17], vegetable residues [18], calcined bones [19], waste bamboo culms [20], and orange and banana peel [21].

Removal of harmful dyes from effluents is an economic fashion that remains a major problem for textile industries [5]. However, high capacity low cost adsorbents are still under development to remove/minimize textile effluents. Waste ash is a leading waste in Woldia town, Ethiopia, which may be thought of as other inexpensive materials used as adsorbents. It has been preferred as it is an easily available waste material mainly coming from hotels, student cafes, and other household activities and stored in a common waste disposal area. It is obtained from plant stems, and charcoal for fuel/thermal energy purposes generates waste ash with no known economic uses. The main plant source used for such purposes is Girar (Acacia bussei). The aim of this work is to study the bioadsorption potential of waste ash for the removal of harmful methylene blue from aqueous solution.

\section{Materials and Methods}

2.1. Preparation of Bioadsorbents. Waste ash, white in color and noncombustible residue, was obtained from the waste disposal area of Woldia town, Ethiopia, as shown in Figure 1. The waste ash used in this experiment was prepared without any treatment (raw) and modified with distilled water (beneficiated) and $1 \mathrm{NH}_{2} \mathrm{SO}_{4}$ (activated) as a ratio of $1: 5$ with continuous stirring for $24 \mathrm{hr}$. The sample mixtures have been filtered and washed several times with distilled water. Filtered waste ash samples were dried at $105^{\circ} \mathrm{C}$ for $24 \mathrm{hr}$, powdered by mortar until the samples were equally fine, sieved in the size of $200 \mu \mathrm{m}$, and kept in desiccators for further use.

2.2. Preparation of Basic Blue Dye (MB) Solution. Basic blue dye (cationic dye) was taken from Kombolcha (S. Wollo) Textile Share Company, Amhara region, Ethiopia. Basic blue dye is powdered solid, soluble in water; it has molecular weight of $319.9 \mathrm{~g} / \mathrm{mol}$ and maximum absorption wavelength of $665 \mathrm{~nm}$; its chemical formula is $\mathrm{C}_{16} \mathrm{H}_{18} \mathrm{ClN}_{3} \mathrm{~S}$; and its IUPAC name is 3,7-bis(dimethylamino)-phenothiazin-5ium chloride. The stock solution $(500 \mathrm{mg} / \mathrm{L})$ of the dye was prepared, and the required concentrations were obtained by serial dilution of the stock solution. The maximum wavelength of the dye $(665 \mathrm{~nm})$ was obtained after full scanning using UV/Vis spectrophotometer (Lambda 35 Perkin Elmer). A linear calibration curve was obtained with different concentrations of methylene blue dye solution as shown in Figure 2.

\subsection{Characterization of Bioadsorbents}

2.3.1. Physiochemical Analysis. The properties of the adsorbents such as moisture content, ash content, volatile matter, fixed carbon, and bulk density were determined according to [22-25] with slight modifications.

Moisture content: about $1 \mathrm{~g}$ of each adsorbent sample was weighed and placed in a clean, dried, weighed, and placed in crucible in a preheated oven at $105^{\circ} \mathrm{C}$ for $4 \mathrm{hr}$. Then, the samples were cooled, kept in desiccators at room temperature, and measured again. The moisture content of the adsorbents was obtained using

$$
\text { moisture content }(\mathrm{MC})=\frac{M_{0}-M_{1}}{M_{0}} \times 100,
$$

where $M_{0}$ and $M_{1}$ are the initial and final mass (g) of the adsorbents, respectively.

Ash content: about $1 \mathrm{~g}$ of each adsorbent sample was placed in crucibles, weighted, and heated in a muffle furnace (Nabertherm B180) under a temperature of $500^{\circ} \mathrm{C}$ for $4 \mathrm{~h}$. After that, the crucibles containing samples were allowed to cool in a desiccator to room temperature and reweighed. The ash content of samples was calculated using

$$
\operatorname{ash} \text { content }(\mathrm{AC})=\frac{\mathrm{Ms}}{\mathrm{Ma}} \times 100,
$$

where Ma and Ms are the mass (g) of the adsorbents and ashes, respectively.

Volatile matter: $1 \mathrm{~g}$ of each adsorbent sample was placed in predried crucibles and heated in a muffle furnace regulated at $500^{\circ} \mathrm{C}$ for $8 \mathrm{~min}$. Then, the crucibles were cooled in desiccators and weighed. Finally, the volatile matter of the adsorbents was calculated using

$$
\text { volatile matter }(\mathrm{VM})=\frac{M_{1}-M_{2}}{M_{1}} \times 100,
$$

where $M_{1}$ and $M_{2}$ are initial mass (g) and final mass (after drying) of adsorbents, respectively.

Fixed carbon: fixed carbon content of adsorbents was determined by subtracting the percentage of $\mathrm{MC}, \mathrm{AC}$, and VM using

fixed carbon content $(\mathrm{FC}) \%=100 \%-(\mathrm{MC}+\mathrm{AC}+\mathrm{VM}) \%$.

Bulk density: the mass to volume ratio of adsorbents was used to determine the bulk density of the adsorbents. A measuring cylinder $(10 \mathrm{~mL}$ volume/size $)$ was weighted. Sufficient amount of the adsorbents was poured into it with constant tapping and filled to the $10 \mathrm{~mL}$ mark. The difference between the initial weight of the container/measuring cylinder and the final weight (container + sample) was calculated. The mass difference was taken as the mass of the adsorbents. Then, the bulk density was calculated from the relationship of mass to volume and determined using

$$
\text { bulk density }\left(\frac{\mathrm{g}}{\mathrm{mL}}\right)=\frac{\text { mass }(\mathrm{g}) \text { of the adsorbent }}{\text { volume }(\mathrm{mL}) \text { of the container }} \text {. }
$$

Surface area determination: the specific surface area of the adsorbents was estimated according to Sears' method [26-28]. About $1.5 \mathrm{~g}$ of raw, beneficiated, and activated waste ash was mixed with $30 \mathrm{~g} \mathrm{NaCl}$ and dissolved by $100 \mathrm{~mL}$ of distilled water using $250 \mathrm{~mL}$ conical flask. The mixtures 

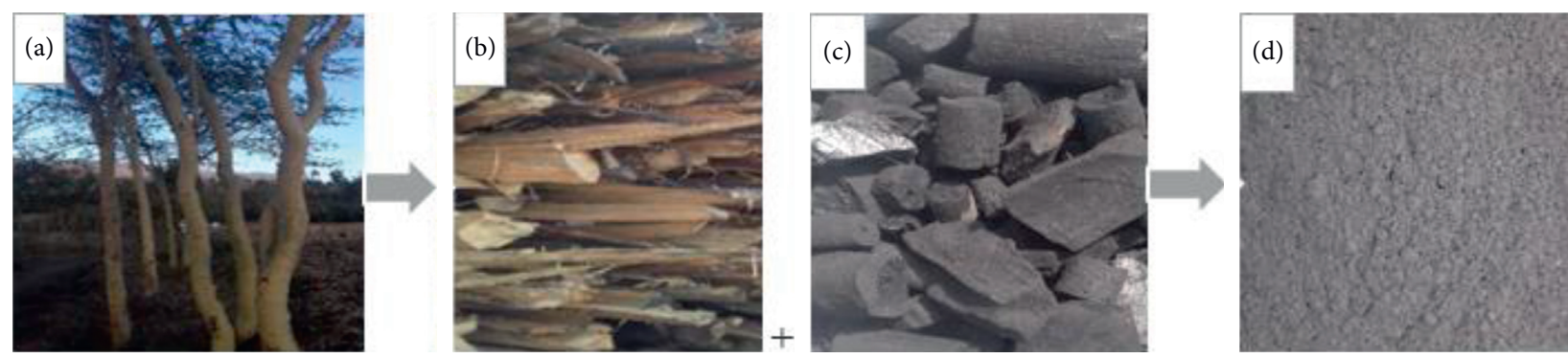

Figure 1: (a) Girar (acacia bussei) tree, (b) stem, (c) charcoal used for fuel source, and (d) disposed waste ash.

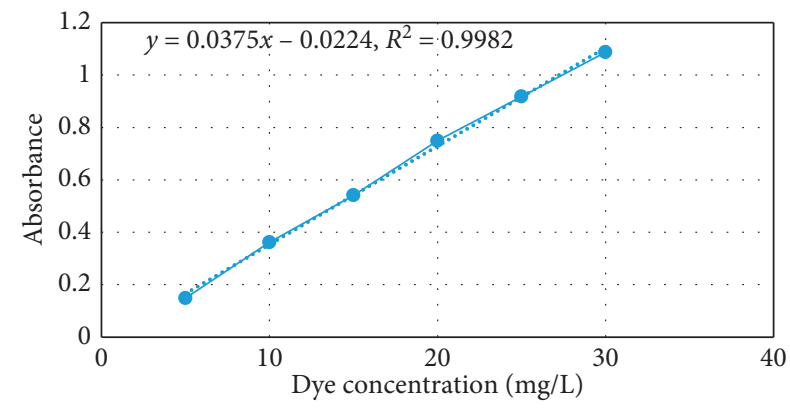

Figure 2: Calibration curve of $\mathrm{MB}$ dye solution at different concentrations.

were stirred for five minutes. Then, the $\mathrm{pH}$ of each solution was adjusted to 4 , and the solutions were titrated by $0.1 \mathrm{M}$ $\mathrm{NaOH}$ until $\mathrm{pH}$ of the solution reaches 9. The volumes of $\mathrm{NaOH}$ required to change $\mathrm{pH}$ value from 4 to 9 were recorded. The specific surface area of each sample was obtained using the following formula:

$$
\text { specific surface area }\left(\frac{\mathrm{m}^{2}}{\mathrm{~g}}\right)=32 . V-25,
$$

where $V$ is the volume of $0.1 \mathrm{M} \mathrm{NaOH}$ required to raise the $\mathrm{pH}$ from 4.0 to 9.0 .

Determination of $\mathrm{pH}$ : raw, beneficiated, and activated waste ash, about $1 \mathrm{~g}$ each, were mixed in $100 \mathrm{~mL}$ of distilled water and continuously stirred for $2 \mathrm{hr}$. The samples were allowed to stabilize before the measurement, and the supernatants were analyzed for $\mathrm{pH}$ using $\mathrm{pH}$ meter [24, 29].

Determination of point of zero charge (PZC): the surface property (surface charge) of the adsorbents was determined by measuring the $\mathrm{pH}$ of zero point charge [30] of raw, beneficiated, and activated waste ash. For the determination of pHPZC, $0.01 \mathrm{M} \mathrm{NaCl}$ was prepared and its initial $\mathrm{pH}$ was adjusted between 2 and 12 by using $1 \mathrm{M} \mathrm{NaOH}$ and $1 \mathrm{M} \mathrm{HCl}$ in each batch. Then, $50 \mathrm{~mL}$ of $0.01 \mathrm{M} \mathrm{NaCl}$ was taken into $250 \mathrm{~mL}$ Erlenmeyer flasks, and $0.20 \mathrm{~g}$ of each adsorbent was added to the solutions. These flasks were kept for $24 \mathrm{~h}$, and the $\mathrm{pH}$ values of the solutions were measured by using a $\mathrm{pH}$ meter. The results were then plotted between final $\mathrm{pH}$ and initial $\mathrm{pH}$. The point of intersection of the curves of "final $\mathrm{pH}$ versus initial $\mathrm{pH}$ " is the $\mathrm{PZC}$ of adsorbents.

2.3.2. FTIR Analysis. The surface functional groups of the bioadsorbents were studied by FTIR spectroscopy (JASCO model 4100). The analyzed samples were prepared by mixing $1 \mathrm{mg}$ of each dried adsorbents with $500 \mathrm{mg}$ of $\mathrm{KBr}$ (spectroscopic grade) in an agate mortar and then pressing the resulting mixture in order to form pellets. Then, FTIR spectra were recorded between 4000 and $400 \mathrm{~cm}^{-1}$.

2.4. Batch Adsorption Experiment. Adsorption experiments were carried out in the batch mode by optimizing different parameters: solution $\mathrm{pH}(4-13)$, contact time (20-120 min), adsorbent dosage $(0.1-2 \mathrm{~g})$, and initial dye concentration (25-100 mg/L). A measure amount of dye sample $(50 \mathrm{~mL})$ and $1.6 \mathrm{~g}$ of adsorbent were taken into $250 \mathrm{~mL}$ conical flask for batch experiment and agitated with magnetic stirrer on digital hot plate at $200 \mathrm{rpm}$. The initial $\mathrm{pH}$ values of all the solutions were adjusted with $1 \mathrm{M} \mathrm{HCl}$ or $1 \mathrm{M} \mathrm{NaOH}$. At the end of each experiment, small amounts of the solutions (supernatants) were withdrawn at predetermined time, and the absorbance was determined using UV/Vis spectrophotometer at a maximum wave length of $665 \mathrm{~nm}$. The adsorption capacity at equilibrium, the methylene blue dye removal (\%), and $q_{e}(\mathrm{mg} / \mathrm{g})$ are shown in the following equations $[25,31,32]$ :

$$
\begin{gathered}
\text { removal efficiency }(\%)=\frac{C_{0}-C_{1}}{C_{0}} \times 100, \\
q_{e}\left(\frac{\mathrm{mg}}{\mathrm{g}}\right)=\frac{\left(C_{0}-C_{1}\right) V}{m},
\end{gathered}
$$

where $C_{0}$ is the initial dye concentration $(\mathrm{mg} / \mathrm{L}), C_{e}$ is the liquid-phase concentrations of the dye $(\mathrm{mg} / \mathrm{L})$ at equilibrium, $V$ is the volume of the dye solution (L), and $m$ is the mass of the adsorbents $(\mathrm{g})$.

\section{Results and Discussion}

\subsection{Characterization of Bioadsorbents}

3.1.1. Physiochemical Characteristics. Physiochemical characteristics of the adsorbents such as moisture content, ash content, volatile matter, fixed carbon, bulk density, solution $\mathrm{pH}$, and point of zero charge were determined and are presented in Table 1. The raw and modified (beneficiated and activated) waste ash had almost similar low moisture contents, which indicates that the adsorption of moisture by the samples is also low. The moisture content has no significant effect on adsorptive power unless it increases the weight and 
TABle 1: Characteristics of raw, beneficiated, and activated waste ash bioadsorbents.

\begin{tabular}{|c|c|c|c|}
\hline \multirow{2}{*}{ Characteristics } & \multicolumn{3}{|c|}{ Bioadsorbents } \\
\hline & Raw & Beneficiated & Activated \\
\hline Moisture content (\%) & 0.011 & 0.014 & 0.085 \\
\hline Volatile matter (\%) & 0.051 & 0.0875 & 0.2898 \\
\hline Ash content $(\%)$ & 1.4594 & 2.427 & 9.612 \\
\hline Fixed carbon $(\%)$ & 98.4756 & 97.4742 & 90.0132 \\
\hline Bulk density $(\mathrm{g} / \mathrm{mL})$ & 0.7463 & 0.7053 & 0.6846 \\
\hline $\mathrm{pH}$ & 11.65 & 11.35 & 8.90 \\
\hline Surface area $\left(\mathrm{m}^{2} / \mathrm{g}\right)$ & 1465 & 1319 & 935 \\
\hline $\mathrm{PZC}$ & 10 & 10 & 8.2 \\
\hline
\end{tabular}

hinders the porous nature of adsorbents [33]. The volatile matter contents were found to increase significantly from raw and beneficiated to activated waste ash (raw $<$ beneficiated $<$ activated). During activation step, organic molecules present in adsorbents become unstable; volatile matter is released as gas and liquid products which evaporate leaving a material [24, 31]; and also significant amounts of mineral matter, carbonates, certain oxides, and sulfides are removed [34]. The result of volatile matter of adsorbents revealed that the active sites of the adsorbents might be removed in the case of activation. The ash contents were also significantly increased from raw and beneficiated to activated waste ashes, causing a decrease in adsorptive properties of adsorbates. A good adsorbent must have low ash content [35]. Ash content can lead to increased hydrophilicity and can have catalytic effects, causing restructuring process during regeneration of used adsorbents $[30,34]$. The fixed carbon contents were found to decrease significantly from raw and beneficiated to activated waste ashes. This could be attributed to the higher competition between activators (water and sulfuric acid) and carbon as well as other elements present in the adsorbent to release more volatile components with concomitant improvement in the textural characteristics and carbon burn-off [23].

The bulk densities were decreased from raw and beneficiated to activated waste ashes. High bulk density is considered to be a good quality of the adsorbent materials [22]. The surface area of raw and modified waste ashes was determined according to Sears' method. Activated waste ash was found to have a low surface area $\left(935 \mathrm{~m}^{2} / \mathrm{g}\right)$ than beneficiated $\left(1319 \mathrm{~m}^{2} / \mathrm{g}\right)$ and raw $\left(1465 \mathrm{~m}^{2} / \mathrm{g}\right)$ waste ashes. The reduced value was due to the high concentration of $\mathrm{H}_{2} \mathrm{SO}_{4}$ that attenuated the pore volume and the surface area [31]. The surface area of activated ash was also reduced due to the presence of significant amount of ash because the presence of these inorganics fills or blocks some of the existing networks of micropores [34] and it occupies some of the open pores of the adsorbent material [36]. The results showed that water treatment also affects the surface area of the waste; this may be due the presence of high ash content compared to the raw material. In addition; water treatment may alter the surface of waste ash through protonation and deprotonation.

The $\mathrm{pH}$ of raw, beneficiated, and activated waste ashes was $11.65,11.35$, and 8.9 , respectively. The results confirmed that the waste ash adsorbents are basic in nature, $\mathrm{pH}>7$. The point of zero charge (PZC) was determined for both raw and modified waste ashes and is presented in Figure 3. It was found to be 10, 10, and 8.2 for raw, beneficiated, and activated waste ashes, respectively. When the $\mathrm{pH}$ of the solution is below the PZC, the surface of the adsorbent will become positively charged, and when the solution $\mathrm{pH}$ is greater than PZC, the surface of the adsorbent will become negatively charged [25]. This implies that the raw, beneficiated, and activated waste ashes most probably adsorb methylene blue dye on basic regions.

3.1.2. FTIR Analysis of Adsorbents. FTIR spectra of the raw, beneficiated, and activated waste ashes are presented in Figure 4. The results show that waste ash adsorbents have many different functional groups due to different adsorption band areas. The intensity of absorption peaks was significantly increased from raw and beneficiated to activated waste ash due to modification of the surface of the adsorbents with water and sulfuric acid. The spectra showed broad band at a range of $3550-3400 \mathrm{~cm}^{-1}$ confirming the presence of the hydroxyl $(\mathrm{O}-\mathrm{H})$ groups of carboxylic acids, alcohols, phenols, and adsorbed water on the surface of adsorbents $[37,38]$. The band at a range of $1615-1430 \mathrm{~cm}^{-1}$ is attributed to $\mathrm{C}=\mathrm{C}$ stretching vibrations, and the peak $<900 \mathrm{~cm}^{-1}$ results of $\mathrm{C}-\mathrm{H}$ (out of plane) confirm the presence of aromatic ring in the adsorbent [34]. The absorption peaks at a range of $1130-1040 \mathrm{~cm}^{-1}$ are attributed to the C-O stretching vibrations.

\subsection{Effects of Experimental Conditions on Adsorption} Efficiency. Effects of solution $\mathrm{pH}$, adsorbent dosage, initial dye concentration, and contact time have been investigated individually for determination of ideal experimental conditions under room temperature.

3.2.1. Effect of Solution pH. Removal efficiency of the adsorbents has been strongly affected by the $\mathrm{pH}$ of the solution in adsorption studies [25]. The effect of initial $\mathrm{pH}$ on adsorption of methylene blue dye by raw, beneficiated, and activated waste ashes was studied in $\mathrm{pH}$ range between 4 and 13, dye concentration of $25 \mathrm{mg} / \mathrm{L}$, and adsorbent dose of $0.4 \mathrm{~g}$ at room temperature, as presented in Figures 5(a) and 5(b). The maximum dye removal by raw, beneficiated, and activated waste ashes was $2.101 \mathrm{mg} / \mathrm{g}(67.244 \%)$ at $\mathrm{pH} 8$, $1.824 \mathrm{mg} / \mathrm{g}(58.368 \%)$ at $\mathrm{pH} 12$, and $1.417 \mathrm{mg} / \mathrm{g}(45.328)$ at $\mathrm{pH} 12$, respectively. The fact that the maximum adsorption of methylene blue was high at higher $\mathrm{pH}$ (at basic region) indicates that the surface of each adsorbent has become negatively charged. Therefore, the mechanism of dye removal was explained via the electrostatic interaction between the negatively charged surface of the adsorbents and the positively charged methylene blue dye adsorbate $[39,40]$.

3.2.2. Effect of Adsorbent Dose. The increase in adsorbent dosage was found to increase the removal efficiency of methylene blue until equilibrium was reached and is 


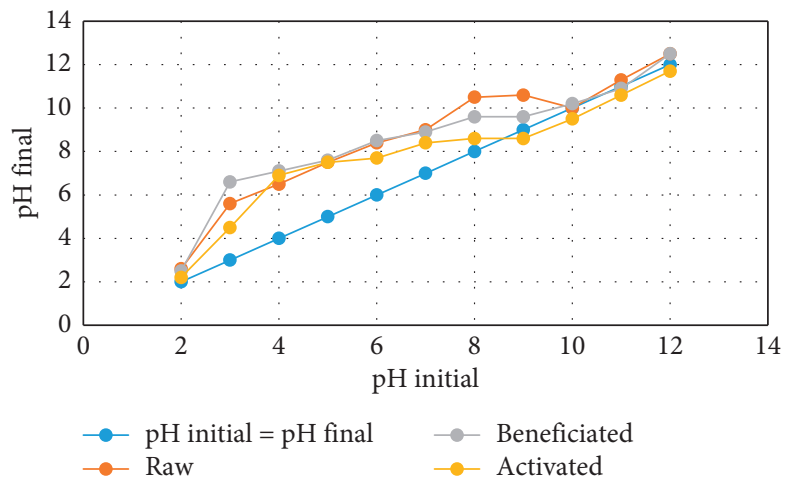

FIgURE 3: Final $\mathrm{pH}$ versus initial $\mathrm{pH}$ for PZC determination of waste ash adsorbents.

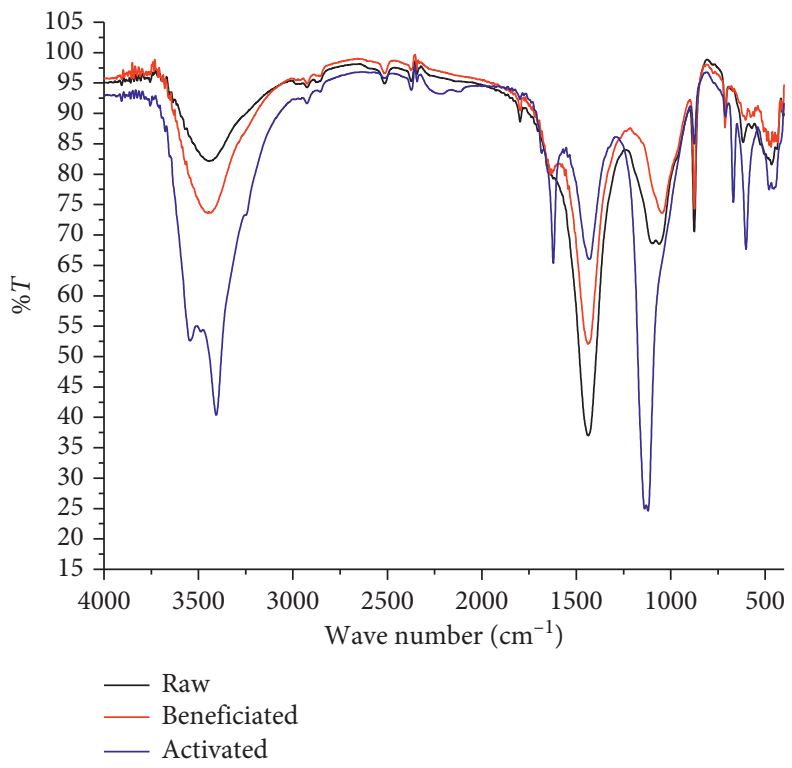

FIGURE 4: FTIR spectra of raw, beneficiated, and activated bioadsorbents.

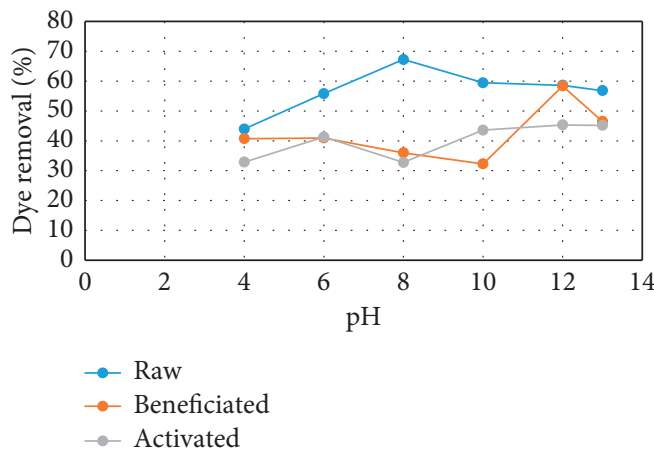

(a)

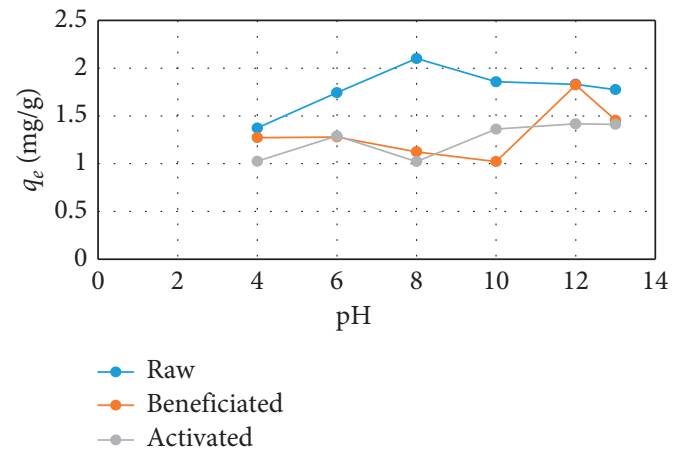

(b)

Figure 5: (a) Effect of $\mathrm{pH}$ on the removal (\%) of $\mathrm{MB}$ by raw, beneficiated, and activated waste ashes. (b) Effect of pH on the adsorption capacity $(\mathrm{mg} / \mathrm{g})$ of $\mathrm{MB}$ by raw, beneficiated, and activated waste ashes.

presented in Figure 6(a). The methylene blue (MB) removal efficiencies of raw, beneficiated, and activated from aqueous solutions were $95.212 \%, 89.172 \%$, and $84.504 \%$, respectively, at optimum dosage value of $1.6 \mathrm{~g}$. Thereafter, no significant change has been observed in all adsorbents, because adsorption saturation was reached or due to overlapping of 


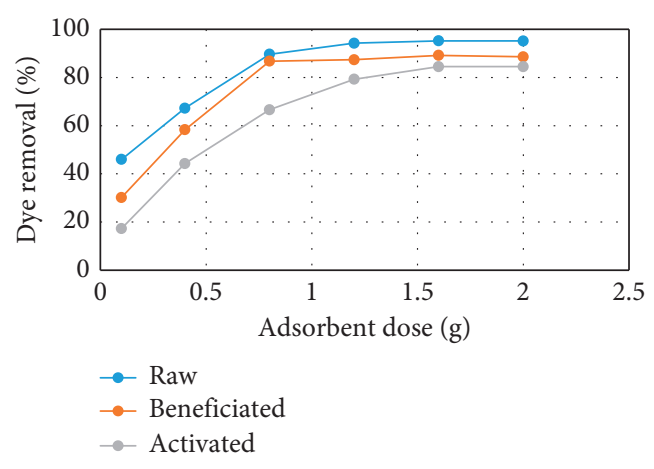

(a)

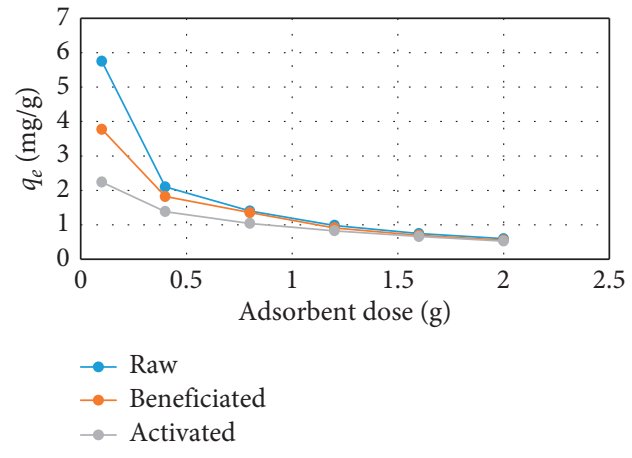

(b)

Figure 6: (a) Effect of adsorbent dosage on MB removal by raw, beneficiated, and activated waste ashes. (b) Effect of adsorbent dosage on $\mathrm{MB}$ adsorption capacity of raw, beneficiated, and activated waste ashes.

adsorption sites as a result of overcrowding of adsorbent particles. As shown in Figure 6(b), the adsorption capacity of adsorbents was found to decrease with increasing the adsorbent dosage, which might be due to the interaction of adsorbent particles like aggregation or agglomeration which results in decrease of the total surface area [4].

3.2.3. Effect of Initial Concentration of Dye. Effects of initial concentration of dye have been examined by using different dye concentrations from 25 to $100 \mathrm{mg} / \mathrm{L}$, as described in Figures $7(\mathrm{a})$ and $7(\mathrm{~b})$. The adsorption capacity increased with increasing the concentration of dye from 0.744 to $2.833 \mathrm{mg} / \mathrm{g}$ for raw, 0.697 to $2.732 \mathrm{mg} / \mathrm{g}$ for beneficiated, and 0.66 to $2.479 \mathrm{mg} / \mathrm{g}$ for activated bioadsorbents. On the other hand, the percentage of removal efficiency of the dye was decreased from $95.212 \%$ to $62.564 \%$ for raw, 89.172 to $49.7 \%$ for beneficiated, and $84.504 \%$ to $17.247 \%$ for activated waste ashes with increasing the initial dye concentration. At a lower initial concentration of methylene blue, there will be unoccupied active sites on the adsorbent surface, and when the initial dye concentration increases, the active sites required for adsorption of the dye molecules will be occupied or saturation of active bioadsorbent sites will be reached [25].

3.2.4. Effect of Contact Time. To examine the minimum time required for maximum performance of adsorbent process, the contact time was varied from 20 to $120 \mathrm{~min}$ at optimum values of adsorbent dose of $1.6 \mathrm{~g}, \mathrm{pH}$ of 4 for raw and 12 for beneficiated and activated adsorbents, and initial dye concentration of $25 \mathrm{mg} / \mathrm{L}$ at room temperature. As shown in Figures 8(a) and 8(b), it has been observed that the removal efficiency and adsorption capacity increase with the increase in contact time up to $100 \mathrm{~min}$, and beyond this time there is no more change. In fact most vacant surface sites are available for adsorption during the initial stage, and the remaining vacant surface sites are hard to adsorb due to repulsive forces between the dye molecules on the adsorbents and the bulk phase.
3.3. Kinetics Study. The kinetic experiments were conducted at the optimal conditions: $\mathrm{pH}=8$ for raw and $\mathrm{pH}=12$ for beneficiated and activated waste ashes, adsorbent dose $1.6 \mathrm{~g}$, initial dye concentration $25 \mathrm{mg} / \mathrm{L}$, and contact time $20-100$ minutes for all adsorbents. Kinetic models have been exploited to test the experimental data and to find the mechanism of adsorption and its potential rate-controlling step that includes mass transport and chemical reaction [41]. In addition, information on the kinetics of dye uptake is required to select the optimum conditions for full scale batch or continuous dye removal processes. Adsorption kinetics is expressed as the solute removal rate that controls the residence time of the sorbate in the solid-solution interface. Mostly used models including the pseudo-first-order and pseudo-second-order ones were applied to the experimental data to evaluate the bioadsorption kinetics of methylene blue dye. The applicability of these kinetic models was determined by measuring the correlation coefficients $\left(R^{2}\right)$ and the experimental $q_{e}$ value $[39,40]$. In order to further understand the characteristics of the adsorption process, the pseudo-first-order and pseudo-second-order kinetic models were applied to fit experimental data obtained from batch experiments and are presented in Figures 9 and 10, respectively. The pseudo-first-order kinetic models are expressed in linear form as follows:

$$
\log \left(q_{e}-q_{t}\right)=\log q_{e}-k_{1} t
$$

where $q_{e}$ is the amount of adsorbate adsorbed at equilibrium $(\mathrm{mg} / \mathrm{g}), q_{t}$ is the amount of solute adsorbed per unit weight of adsorbent at time $(\mathrm{mg} / \mathrm{g})$, and $k_{1}$ is the rate constant of pseudo-first-order sorption (1/hr) [25]. The values of $k_{1}$ and $q_{e}$ were calculated from the slope and intercept of $\log \left(q_{e}-q_{t}\right)$ vs $t$ graph, respectively, and the results are presented in Table 2 for all adsorbents.

The result of pseudo-second-order model is shown in Figure 10 and expressed in (10) in linearized form as follows:

$$
\frac{t}{q_{t}}=\frac{1}{k_{2} q_{e}^{2}}+\frac{t}{q_{e}}
$$

where $k_{2}\left(\mathrm{~g} \cdot \mathrm{mg}^{-1} \cdot \mathrm{min}^{-1}\right)$ is the rate constant of the pseudosecond-order adsorption, $q_{e}$ is the amount of dye adsorbed 


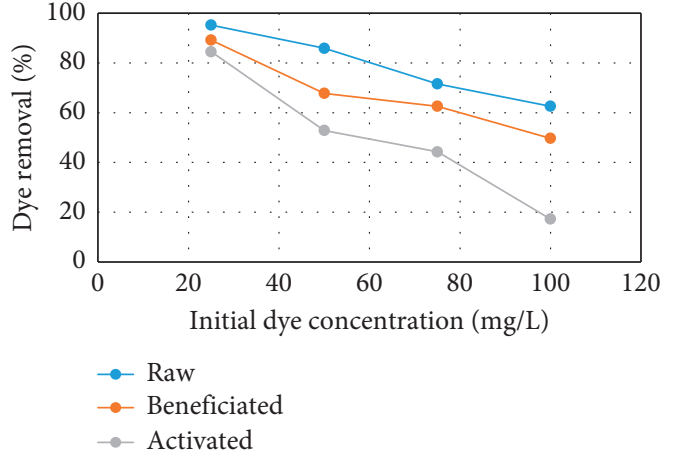

(a)

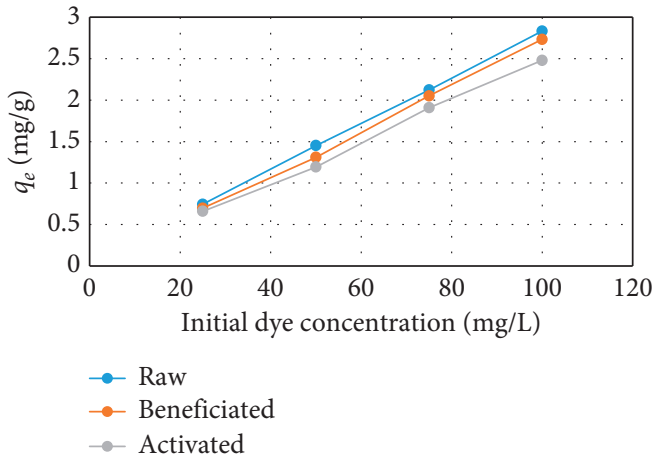

(b)

Figure 7: (a) Effect of initial dye concentration on MB dye removal by raw, beneficiated, and activated adsorbents. (b) Effect of initial dye concentration on $\mathrm{MB}$ dye adsorption capacity by raw, beneficiated, and activated adsorbents.

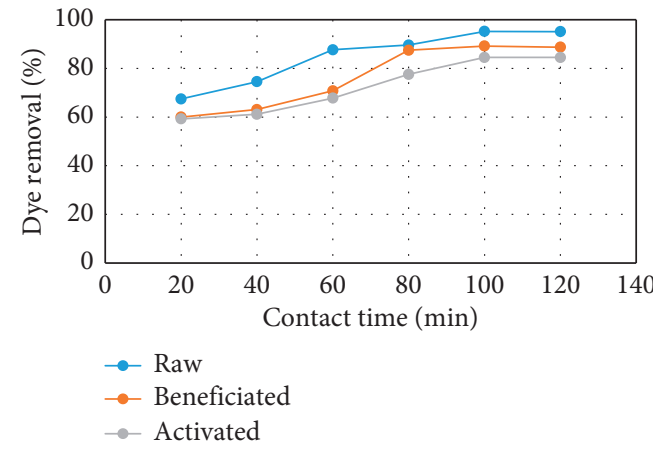

(a)

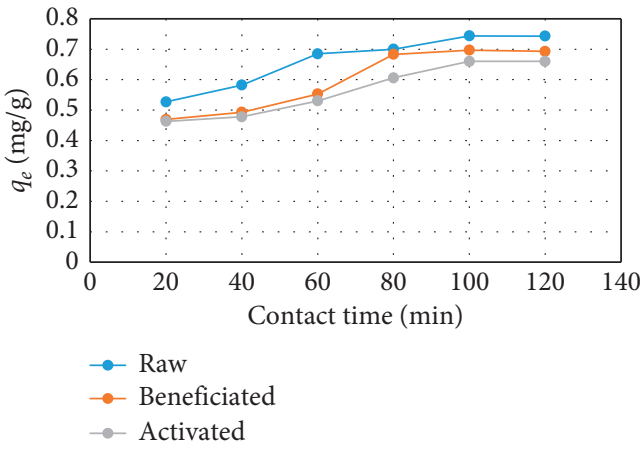

(b)

Figure 8: (a) Effect of contact time on MB dye removal efficiency by raw, beneficiated, and activated adsorbents. (b) Effect of contact time on MB dye adsorption capacity by raw, beneficiated, and activated adsorbents.

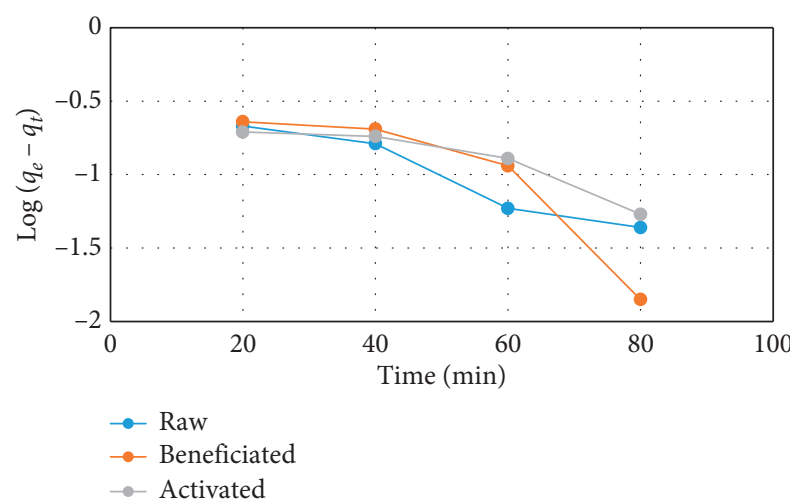

Figure 9: Pseudo-first-order kinetics model for all adsorbents at $50 \mathrm{~mL}$ of $25 \mathrm{mg} / \mathrm{L}$ of $\mathrm{MB}$ concentration.

on the adsorbent at equilibrium $(\mathrm{mg} / \mathrm{g})$, and $q_{t}$ is the amount of dye adsorbed on the adsorbent at any time, $t(\mathrm{mg} / \mathrm{g})$. The values of $k_{2}$ and $q_{e}$ were calculated from slope and intercept of $t / q_{t}$ vs $t$ graph, respectively.

The kinetic parameters and the correlation coefficients $\left(R^{2}\right)$ were determined from nonlinear regression. Figures 9 and 10 represent pseudo- $1^{\text {st }}$ and $-2^{\text {nd }}$ order kinetics,

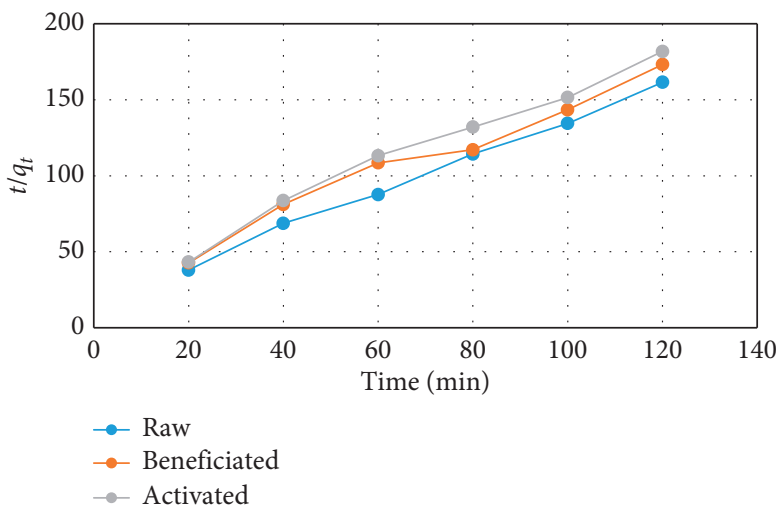

FIgURE 10: Pseudo-second-order kinetics model for all adsorbents at $50 \mathrm{~mL}$ of $25 \mathrm{mg} / \mathrm{L}$ of $\mathrm{MB}$ concentration.

respectively, and their parameters are presented in Table 2. The calculated $q_{e}$ values $\left(q_{e}, \mathrm{cal}\right)$ of pseudo- $2^{\text {nd }}$ order model are close to the experimental ones $\left(q_{e}, \exp \right)$ as compared to pseudo- $1^{\text {st }}$ order kinetics model. The $R^{2}$ values also for the pseudo-second-order kinetic model are close to 1 , which indicates that experimental data were in good agreement with pseudo-second kinetics order model. 
TABLE 2: Kinetic parameters for MB adsorption on raw, beneficiated, and activated ash.

\begin{tabular}{lcccccrrr}
\hline \multirow{2}{*}{ Adsorbent type Concentration $(\mathrm{mg} / \mathrm{L})$} & $q_{e}$ exp. $(\mathrm{mg} / \mathrm{g})$ & \multicolumn{3}{c}{ Pseudo-1 ${ }^{\text {st }}$ order } & \multicolumn{3}{c}{ Pseudo- ${ }^{\text {nd }}$ order } \\
& & & $K_{1}\left(\mathrm{~min}^{-1}\right)$ & $q_{e}$ calc. $(\mathrm{mg} / \mathrm{g})$ & $R^{2}$ & $K_{2}\left(\mathrm{~min}^{-1}\right)$ & $q_{e}$ calc. $(\mathrm{mg} / \mathrm{g})$ & $R^{2}$ \\
\hline Raw & 25 & 0.744 & -0.0126 & 0.412 & 0.9407 & 0.087 & 0.69 \\
Beneficiated & 25 & 0.697 & -0.0194 & 0.871 & 0.7938 & 0.056 & 0.9967 \\
Activated & 25 & 0.660 & -0.0091 & 0.359 & 0.8428 & 0.065 & 0.9764 \\
\hline
\end{tabular}

3.4. Adsorption Isotherms. In order to study how the molecules of MB interact with the adsorbent surface, the adsorption isotherms were used to analyze the experimental data. Isotherms study can describe how an adsorbate interacts with an adsorbent $[42,43]$. The isotherm provides a relationship between the concentration of dye in solution and the amount of dye adsorbed on the solid phase when both phases are in equilibrium. The most widely used isotherm equations are Langmuir and Freundlich equations. These two isotherms have their own assumptions that explain the adsorption mechanism, and they are presented in Figures 11 and 12, respectively. The Langmuir model is used to describe the formation of monolayer adsorbate on the outer surface of the adsorbent. It is often applicable to a homogeneous adsorption surface with all the adsorption sites having equal adsorbate affinity, while Freundlich isotherm assumes that during the adsorption process different sites of the adsorbent with several adsorption energies are involved, which is an empirical relation for adsorption over heterogeneous surfaces. The linear expression of Langmuir isotherm model can be illustrated as follows:

$$
\frac{C_{e}}{q_{e}}=\frac{1}{b q_{m}}+\frac{C_{e}}{q_{m}},
$$

where $C_{e}$ is the equilibrium concentration of solute (mmol $\left.\mathrm{L}^{-1}\right), q_{e}$ is the amount of solute adsorbed per unit weight of adsorbent (mmol.g ${ }^{-1}$ of adsorbate), $q_{m}$ is the adsorption capacity $\left(\mathrm{mmol} \cdot \mathrm{g}^{-1}\right)$, or monolayer capacity, and $b$ is a constant $\left(\mathrm{L} \cdot \mathrm{mmol}^{-1}\right)$. The isotherm parameters $b$ and $q_{m}$ were determined from the intercept and the slope of $C_{e} / q_{e}$ versus $C_{e}$ graph, respectively. The linear expression of Freundlich isotherm model can be illustrated as follows:

$$
\log q_{e}=\log k_{f}+\frac{\log C_{e}}{n},
$$

where $K_{f}$ and $n$ are empirical constants incorporating all parameters affecting the adsorption process such as sorption capacity and sorption intensity, respectively [44]. The isotherm parameters $K_{f}$ and $n$ were calculated from the $\log q_{e}$ vs $\log C_{e}$ graph and are presented in Table 3. For the Freundlich isotherm if $n=1$, then the partition between the two phases is independent of the concentration. If value of $1 / n$ is below one, it indicates a normal adsorption. On the other hand, $1 / n$ being above one indicates cooperative adsorption. For this study, as shown in Table 3, the values of $1 / n$ were below 1 for all adsorbents, which confirms that adsorption of $\mathrm{MB}$ on these adsorbents was normal adsorption.

The essential characteristics of the Langmuir isotherm can be expressed in terms of a dimensionless constant separation factor $R_{L}$ given by the relation in (13) that can be

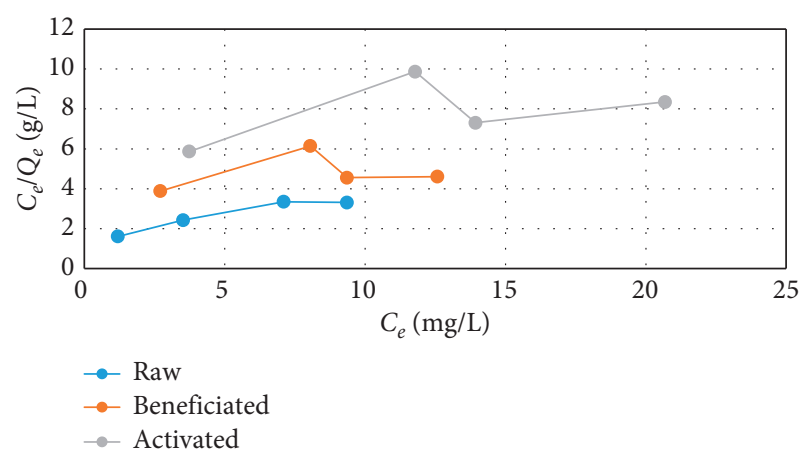

Figure 11: Langmuir isotherm model for different adsorbents (raw, beneficiated, and activated ash) at constant dosage $25 \mathrm{mg} / \mathrm{L}, \mathrm{pH}$ optimum 8 for raw and 12 for beneficiate and activated ash, contact time $100 \mathrm{~min}$, shaker speed $100 \mathrm{rpm}$, room temperature, and concentration $25-100 \mathrm{mg} / \mathrm{L}$ within $25 \mathrm{mg} / \mathrm{L}$ intervals.

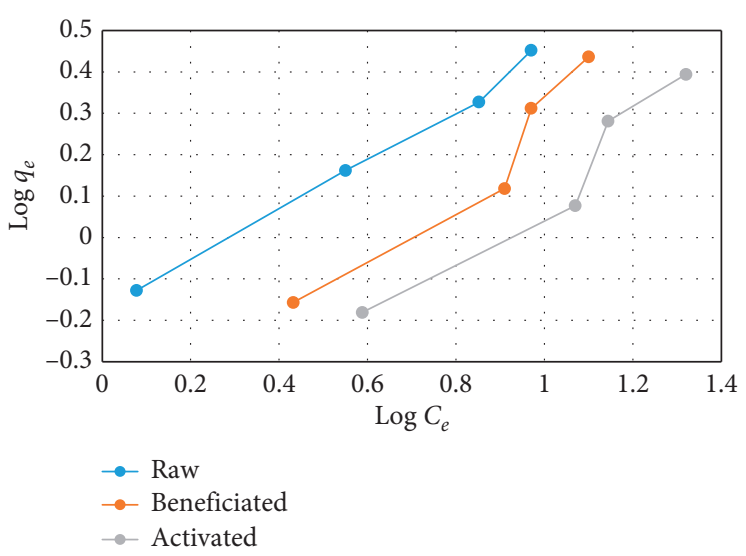

FIGURE 12: Freundlich isotherm model for different adsorbents (raw, beneficiated, and activated ash) at constant dosage $25 \mathrm{mg} / \mathrm{L}$, $\mathrm{pH}$ optimum 8 for raw and 12 for beneficiate and activated ash, contact time $100 \mathrm{~min}$, shaker speed $100 \mathrm{rpm}$, room temperature, and concentration $25-100 \mathrm{mg} / \mathrm{L}$ within $25 \mathrm{mg} / \mathrm{L}$ intervals.

used to determine the feasibility of adsorption in a given concentration range over adsorbent $[41,45,46]$ :

$$
\mathrm{RL}=\frac{1}{1+b C_{0}},
$$

where $b$ is Langmuir constant related to the energy of adsorption $\left(\mathrm{L} \cdot \mathrm{mg}^{-1}\right)$ and $C_{0}$ is initial concentration $(\mathrm{mg} / \mathrm{L})$. The calculated $R_{L}$ values at different initial dye concentrations are listed in Table $4 . R_{L}$ value indicates the adsorption nature to be either unfavorable if $R_{L}>1$, linear if $R_{L}=1$, favorable if 
TABLE 3: Dimensionless constant separation factor $\left(R_{L}\right)$ value for different adsorbents at different initial concentrations.

$$
R_{L} \text { values }
$$

Adsorbent type Concentration $(\mathrm{mg} / \mathrm{L})$

\begin{tabular}{lcccc} 
& 25 & 50 & 75 & 100 \\
\hline Raw & 0.22 & 0.12 & 0.09 & 0.07 \\
Beneficiated & 0.09 & 0.53 & 0.43 & 0.36 \\
Activated & 0.66 & 0.49 & 0.39 & 0.32 \\
\hline
\end{tabular}

TABLE 4: Isotherm parameters obtained from isotherm graphs for all adsorbents.

\begin{tabular}{lccc}
\hline $\begin{array}{l}\text { Adsorbent } \\
\text { type }\end{array}$ & Isotherm & $R^{2}$ & $\begin{array}{c}\text { Estimated isotherm } \\
\text { parameters }\end{array}$ \\
\hline \multirow{4}{*}{ Raw } & Langmuir & 0.907 & $\begin{array}{c}b=0.142 \mathrm{~L} / \mathrm{mg} \\
q_{m}=4.62 \mathrm{mg} / \mathrm{g}\end{array}$ \\
& Freundlich & 0.993 & $n=1.59 K_{f}=1.52 \mathrm{mg} / \mathrm{g}$ \\
Beneficiated & Langmuir & 0.1014 & $b=0.018 \mathrm{~L} / \mathrm{mg} q_{m}=13.51 \mathrm{mg} / \mathrm{g}$ \\
& Freundlich & 0.9212 & $n=1.78 K_{f}=3.53 \mathrm{mg} / \mathrm{g}$ \\
Activated & Langmuir & 0.2954 & $b=0.021 \mathrm{~L} / \mathrm{mg}$ \\
& Freundlich & 0.9326 & $n=1.28 K_{f}=4.57 \mathrm{mg} / \mathrm{g}$ \\
\hline
\end{tabular}

$0<R_{L}<1$, and irreversible if $R_{L}=0$ [46]. For this study, all the values lied between 0 and 1 , confirming that the adsorption of dye over the adsorbent was favorable.

All isotherm parameters for both isotherms are presented in Table 4, and the $R^{2}$ values of Freundlich isotherm are greater than those of Langmuir model for all adsorbents, which confirms that Freundlich isotherm is suitable for describing the adsorption equilibrium of $\mathrm{MB}$ onto these adsorbents.

\section{Conclusion}

In summary, this experimental study showed that the removal of methylene blue through adsorption on raw, beneficiated, and activated waste ash adsorbents is an effective, economical, safe, and eco-friendly alternative. The adsorption potential obtained using raw waste ash is higher than that using the same dose of beneficiated and activated bioadsorbents. In fact water and sulfuric acid treatment causes a significant reduction in the total surface area, enhancement of ash content, and reduction of fixed carbon and promotes the formation of acidic surface groups via protonation. The adsorption kinetics was in good agreement with pseudo-second-order kinetic model, and the adsorption isotherm showed good fitting to Freundlich isotherm model. This study clearly shows that adsorption strongly depends on solution $\mathrm{pH}$, adsorbent dose, dye concentration, and contact time of the experimental parameters.

\section{Abbreviations}

FTIR: Fourier transform infrared spectroscopy

UV/Vis: Ultraviolet visible spectroscopy

PZC: Point of zero charge

AC: $\quad$ Ash content $\begin{array}{ll}\text { MC: } & \text { Moisture content } \\ \text { VM: } & \text { Volatile matter }\end{array}$

FC: $\quad$ Fixed carbon.

\section{Data Availability}

All data generated or analyzed during this study are included within the article.

\section{Conflicts of Interest}

The authors declare that they have no conflicts of interest.

\section{Authors' Contributions}

All the authors contributed to experimental work, data analysis, and manuscript writing, editing, and final approval.

\section{Acknowledgments}

The authors gratefully acknowledge Woldia University for laboratory facility to conduct this research work. This study was fully self-funded.

\section{References}

[1] A. K. Kushwaha, N. Gupta, and M. C. Chattopadhyaya, "Removal of cationic methylene blue and malachite green dyes from aqueous solution by waste materials of Daucus carota," Journal of Saudi Chemical Society, vol. 18, no. 3, pp. 200-207, 2014.

[2] P. Sharma, "Removal of methylene blue from aqueous waste using rice husk and rice husk ash," Desalination, vol. 259, no. 1-3, pp. 249-257, 2010.

[3] M. Ertaş, B Acemioğlu, M. H Alma, and M. Usta, "Removal of methylene blue from aqueous solution using cotton stalk, cotton waste and cotton dust," Journal of Hazardous Materials, vol. 183, no. 1-3, pp. 421-427, 2010.

[4] S. Shakoor and A. Nasar, "Removal of methylene blue dye from artificially contaminated water using citrus limetta peel waste as a very low cost adsorbent," Journal of the Taiwan Institute of Chemical Engineers, vol. 66, pp. 154-163, 2016.

[5] R. Subramaniam and S. Kumar Ponnusamy, "Novel adsorbent from agricultural waste (cashew nut shell) for methylene blue dye removal: optimization by response surface methodology," Water Resources and Industry, vol. 11, pp. 64-70, 2015.

[6] C. Ozer, M. Imamoglu, Y. Turhan, and F. Boysan, "Removal of methylene blue from aqueous solutions using phosphoric acid activated carbon produced from hazelnut husks," Toxicological \& Environmental Chemistry, vol. 94, no. 7, pp. 1283-1293, 2012.

[7] N. Gupta, A. K. Kushwaha, and M. C. Chattopadhyaya, "Application of potato (Solanum tuberosum) plant wastes for the removal of methylene blue and malachite green dye from aqueous solution," Arabian Journal of Chemistry, vol. 9, pp. S707-S716, 2016.

[8] W.-T. Tsai, K.-J. Hsien, H.-C. Hsu, C.-M. Lin, K.-Y. Lin, and C.-H. Chiu, "Utilization of ground eggshell waste as an adsorbent for the removal of dyes from aqueous solution," Bioresource Technology, vol. 99, no. 6, pp. 1623-1629, 2008.

[9] A. K. Kushwaha, N. Gupta, and M. Chattopadhyaya, "Enhanced adsorption of methylene blue on modified silica gel: equilibrium, kinetic, and thermodynamic studies," 
Desalination and Water Treatment, vol. 52, no. 22-24, pp. 4527-4537, 2014.

[10] R. K. Ghosh and D. D. Reddy, "Tobacco stem ash as an adsorbent for removal of methylene blue from aqueous solution: equilibrium, kinetics, and mechanism of adsorption," Water, Air, \& Soil Pollution, vol. 224, no. 6, p. 1582, 2013.

[11] X.-G. Chen, S.-S. Lv, S.-T. Liu et al., "Adsorption of methylene blue by rice hull ash," Separation Science and Technology, vol. 47, no. 1, pp. 147-156, 2012.

[12] L. Borah, M. Goswami, and P. Phukan, "Adsorption of methylene blue and eosin yellow using porous carbon prepared from tea waste: adsorption equilibrium, kinetics and thermodynamics study," Journal of Environmental Chemical Engineering, vol. 3, no. 2, pp. 1018-1028, 2015.

[13] A. Reffas, "Carbons prepared from coffee grounds by $\mathrm{H}_{3} \mathrm{PO}_{4}$ activation: characterization and adsorption of methylene blue and Nylosan Red N-2RBL," Journal of Hazardous Materials, vol. 175, no. 1-3, pp. 779-788, 2010.

[14] F. Marrakchi, M. Auta, W. A. Khanday, and B. H. Hameed, "High-surface-area and nitrogen-rich mesoporous carbon material from fishery waste for effective adsorption of methylene blue," Powder Technology, vol. 321, pp. 428-434, 2017.

[15] A. M. Aljeboree, A. N. Alshirifi, and A. F. Alkaim, "Kinetics and equilibrium study for the adsorption of textile dyes on coconut shell activated carbon," Arabian Journal of Chemistry, vol. 10, pp. S3381-S3393, 2017.

[16] S. Rangabhashiyam, N. Anu, and N. Selvaraju, "Sequestration of dye from textile industry wastewater using agricultural waste products as adsorbents," Journal of Environmental Chemical Engineering, vol. 1, no. 4, pp. 629-641, 2013.

[17] P. Sathishkumar, M. Arulkumar, and T. Palvannan, "Utilization of agro-industrial waste Jatropha curcas pods as an activated carbon for the adsorption of reactive dye remazol brilliant blue R (RBBR)," Journal of Cleaner Production, vol. 22, no. 1, pp. 67-75, 2012.

[18] A.-A. Peláez-Cid, A.-M. Herrera-González, M. Salazar-Villanueva, and A. Bautista-Hernández, "Elimination of textile dyes using activated carbons prepared from vegetable residues and their characterization," Journal of Environmental Management, vol. 181, pp. 269-278, 2016.

[19] M. El Haddad, R. Slimani, R. Mamouni, S. ElAntri, and S. Lazar, "Removal of two textile dyes from aqueous solutions onto calcined bones," Journal of the Association of Arab Universities for Basic and Applied Sciences, vol. 14, no. 1, pp. 51-59, 2013.

[20] L. Wang, "Application of activated carbon derived from "waste" bamboo culms for the adsorption of azo disperse dye: kinetic, equilibrium and thermodynamic studies," Journal of Environmental Management, vol. 102, pp. 79-87, 2012.

[21] R. Mane and V. Bhusari, "Removal of colour (dyes) from textile effluent by adsorption using orange and banana peel," International Journal of Engineering Research and Applications, vol. 2, no. 3, pp. 1997-2004, 2012.

[22] J. Fito, "Fluoride removal from aqueous solution onto activated carbon of Catha edulis through the adsorption treatment technology," Environmental Systems Research, vol. 8, no. 1, p. 25, 2019.

[23] S. Mopoung, P. Moonsri, W. Palas, and S. Khumpai, "Characterization and properties of activated carbon prepared from tamarind seeds by $\mathrm{KOH}$ activation for Fe (III) adsorption from aqueous solution," The Scientific World Journal, vol. 2015, Article ID 415961, 9 pages, 2015.

[24] O. S. Bello, K. A. Adegoke, and O. O. Akinyunni, "Preparation and characterization of a novel adsorbent from Moringa oleifera leaf," Applied Water Science, vol. 7, no. 3, pp. 12951305, 2017.

[25] F. Temesgen, N. Gabbiye, and O. Sahu, "Biosorption of reactive red dye (RRD) on activated surface of banana and orange peels: economical alternative for textile effluent," Surfaces and Interfaces, vol. 12, pp. 151-159, 2018.

[26] H. Dargo, N. Gabbiye, and A. Ayalew, "Removal of methylene blue dye from textile wastewater using activated carbon prepared from rice husk," Canadian Entomologist, vol. 9, pp. 317-325, 2014.

[27] R. Rehman, "Influence of operating conditions on the removal of brilliant vital red dye from aqueous media by biosorption using rice husk," Journal of Chemical Society of Pakistan, vol. 33, no. 4, 2011.

[28] B. Evbuomwan and J. Alalibo, "Proximate and ultimate analysis of walnut shell as a potential low cost adsorbent using different activating agents $\left(\mathrm{KOH}\right.$ and $\left.\mathrm{H}_{2} \mathrm{SO}_{4}\right)$," Chemistry Research Journal, vol. 2, no. 5, pp. 124-130, 2018.

[29] A. Mittal, J. Mittal, and L. Kurup, "Adsorption isotherms, kinetics and column operations for the removal of hazardous dye, tartrazine from aqueous solutions using waste materialsbottom ash and de-oiled soya, as adsorbents," Journal of Hazardous Materials, vol. 136, no. 3, pp. 567-578, 2006.

[30] D. Kibami, "Preparation and characterization of activated carbon from Fagopyrum esculentum Moench by $\mathrm{HNO}_{3}$ and $\mathrm{H}_{3} \mathrm{PO}_{4}$ chemical activation," Der Chemica Sinica, vol. 5, no. 4, pp. 46-55, 2014.

[31] A. H. Jawad, R. Razuan, J. N. Appaturi, and L. D. Wilson, "Adsorption and mechanism study for methylene blue dye removal with carbonized watermelon (Citrullus lanatus) rind prepared via one-step liquid phase $\mathrm{H}_{2} \mathrm{SO}_{4}$ activation," Surfaces and Interfaces, vol. 16, pp. 76-84, 2019.

[32] T. A. Aragaw and F. T. Angerasa, "Adsorption of basic yellow dye dataset using Ethiopian kaolin as an adsorbent," Data in Brief, vol. 26, Article ID 104504, 2019.

[33] A. H. Jawad, S. Sabar, M. A. M. Ishak et al., "Microwaveassisted preparation of mesoporous-activated carbon from coconut (Cocos nucifera) leaf by $\mathrm{H}_{3} \mathrm{PO}_{4}$ activation for methylene blue adsorption," Chemical Engineering Communications, vol. 204, no. 10, pp. 1143-1156, 2017.

[34] F. Ahmad, W. M. A. W. Daud, M. A. Ahmad, and R. Radzi, "The effects of acid leaching on porosity and surface functional groups of cocoa (Theobroma cacao)-shell based activated carbon," Chemical Engineering Research and Design, vol. 91, no. 6, pp. 1028-1038, 2013.

[35] D. Malik, "Preparation and characterization of plant based low cost adsorbents," Journal of Global Bioscience, vol. 4, no. 1, pp. 1824-1829, 2015.

[36] P. Leechart, W. Nakbanpote, and P. Thiravetyan, "Application of "waste" wood-shaving bottom ash for adsorption of azo reactive dye," Journal of Environmental Management, vol. 90, no. 2, pp. 912-920, 2009.

[37] Y. Gokce and Z. Aktas, "Nitric acid modification of activated carbon produced from waste tea and adsorption of methylene blue and phenol," Applied Surface Science, vol. 313, pp. 352359, 2014.

[38] G. Zhu, X. Xing, J. Wang, and X. Zhang, "Effect of acid and hydrothermal treatments on the dye adsorption properties of biomass-derived activated carbon," Journal of Materials Science, vol. 52, no. 13, pp. 7664-7676, 2017.

[39] D. Pathania, S. Sharma, and P. Singh, "Removal of methylene blue by adsorption onto activated carbon developed from Ficus carica bast," Arabian Journal of Chemistry, vol. 10, pp. S1445-S1451, 2017. 
[40] S. Sadaf and H. N. Bhatti, "Batch and fixed bed column studies for the removal of indosol yellow BG dye by peanut husk," Journal of the Taiwan Institute of Chemical Engineers, vol. 45, no. 2, pp. 541-553, 2014.

[41] L. Ai, C. Zhang, F. Liao et al., "Removal of methylene blue from aqueous solution with magnetite loaded multi-wall carbon nanotube: kinetic, isotherm and mechanism analysis," Journal of Hazardous Materials, vol. 198, pp. 282-290, 2011.

[42] M. Ghaedi, A. G. Nasab, S. Khodadoust, M. Rajabi, and S. Azizian, "Application of activated carbon as adsorbents for efficient removal of methylene blue: kinetics and equilibrium study," Journal of Industrial and Engineering Chemistry, vol. 20 , no. 4, pp. 2317-2324, 2014

[43] K. Gobi, M. D. Mashitah, and V. M. Vadivelu, "Adsorptive removal of methylene blue using novel adsorbent from palm oil mill effluent waste activated sludge: equilibrium, thermodynamics and kinetic studies," Chemical Engineering Journal, vol. 171, no. 3, pp. 1246-1252, 2011.

[44] C. A. P. Almeida, N. A. Debacher, A. J. Downs, L. Cottet, and C. A. D. Mello, "Removal of methylene blue from colored effluents by adsorption on montmorillonite clay," Journal of Colloid and Interface Science, vol. 332, no. 1, pp. 46-53, 2009.

[45] Y. Li, Q. Du, T. Liu et al., "Comparative study of methylene blue dye adsorption onto activated carbon, graphene oxide, and carbon nanotubes," Chemical Engineering Research and Design, vol. 91, no. 2, pp. 361-368, 2013.

[46] E. Ajenifuja, J. A. Ajao, and E. O. B. Ajayi, "Adsorption isotherm studies of $\mathrm{Cu}$ (II) and Co (II) in high concentration aqueous solutions on photocatalytically modified diatomaceous ceramic adsorbents," Applied Water Science, vol. 7, no. 7, pp. 3793-3801, 2017. 